\title{
The EU's Difficulty in Translating Interests into Effective Foreign Policy Action: A Look at the Ukraine Crisis
}

\author{
Nicholas Ross Smith \\ Politics and International Relations, \\ University of Auckland \\ Private Bag 92019, \\ Auckland, New Zealand \\ E-mail: nrsmith@outlook.co.nz
}

\begin{abstract}
The EU's foreign policy response(s) to the unfolding Ukraine crisis has further illustrated its difficulty in making effective foreign policy decisions. Using a neoclassical realist analytical framework, this paper argues that although the EU did have tangible collective interests in pursuing its Ukraine foreign policy, it was unable to adequately filter these through its domestic setting. Three key constraints to the EU's Ukrainian foreign policy were identified: decision-makers' miscalculations; rigid normative demands; and a reliance on consensus politics. Ultimately, the Ukraine crisis illustrated that the EU, in current incarnation, cannot translate interests into effective foreign policies, even when making policy for their direct neighbourhood.
\end{abstract}

Keywords: EU foreign policy, neoclassical realism, Ukraine

\section{Introduction}

This paper examines the EU's foreign policy towards Ukraine in light of the crisis which erupted in the wake of Viktor Yanukovych's decision to not sign the offered Association Agreement (AA). Through analysing the EU's systemic power position in conjunction with surveying both the official policy documents and the opinions of EU officials, an argument is made that the EU had concrete 
interests in developing its foreign policy towards Ukraine. However, using the foreign policy analysis framework of neoclassical realism, it is argued that due to a number of intervening factors, the EU was unable to translate its interests into effective foreign policy action in Ukraine. ${ }^{1}$

The notion of the EU as representing a sui generis actor which pursues normative foreign policy aims, particularly in its neighbourhood, has become engrained in the literature over the past decade (Whitman, 2011). However, through focussing predominately on the ideational drivers of EU foreign policy, this branch of literature has almost entirely forgotten the role of structure and materialism (Toje \& Kunz, 2012). Emblematically, the literature is now replete with monikers about what sort of power the EU is: whether civilian, civilising, soft, normative, small, metrosexual, ethical, and so on (Forsberg, 2013). Arguably, these studies are too conceptually focussed, while at the same time being theoretically weak and empirically untested. Consequently, this paper calls for a re-engagement with the pragmatism of foreign policy analysis, which instead of asking what the $\mathrm{EU}$ is, focusses on what the EU does.

This paper adopts a rationalist and non-sui generis approach, neoclassical realism, to analyse the Union's foreign policy decisions. Neoclassical realism represents a theoretically-informed and problem-driven analytical framework which understands foreign policy as being primarily a product of systemic pressures (i.e. an entity's relative power position in the international system) which are mediated and redirected by the domestic-level setting, particularly the perceptions held by decision-makers and the domestic constraints on exercising power (Rose, 1998). Consequently, neoclassical realism argues that an entity is prescribed an ideal foreign policy decision by the international system, but this has to be filtered through the domestic setting which results in divergent and constrained foreign policy decisions. ${ }^{2}$

With regards to analysing EU foreign policy, a neoclassical realism-inspired approach starts with examination of the EU's relative power position in the international system which, it is argued, just as is the case with states, encourages or discourages particular action (Hyde-Price, 2007; Brooks \& Wohlforth, 2010).

1 In the scope of this paper, "effective foreign policy action" for the EU is defined as its ability to achieve stated, and deduced, goals. Effectiveness is argued as being a product of coherency and actorness. Coherency, as defined by Thomas (2012, p. 458), represents "the adoption of determinate common policies and the pursuit of those policies by EU Member States and institutions." Actorness, as defined by Sjöstedt (1977, p. 16) represents "the capacity [of the EU] to behave actively and deliberately in relation to other actors in the international system".

2 Because of this, Schweller (2004) coined neoclassical realism a "theory of mistakes". 
However, to move beyond a purely structural realist analysis, this paper asserts that factoring in the EU's foreign policy decision-makers' perceptions, ${ }^{3}$ the constraining impact of Member States' preferences, and the EU's normative power role identity are necessary in order to understand the ultimate foreign policy decision.

\section{The EU's foreign policy towards Ukraine: examining the inherent interests of the Association Agreement offer.}

The EU's foreign policy towards Ukraine presents an ideal case to test the EU's foreign policy decisions under the scope of neoclassical realism as Ukraine is the largest and most attractive country in the EU's Eastern Neighbourhood; an area of great interest for the EU. ${ }^{4}$ Since the EU's enlargement eastwards in 2004 and 2007, during which ten erstwhile communist states joined the Union, the remaining corridor of states (Belarus, Moldova and Ukraine) that lie between the EU and Russia has become an important focus of the EU's external policy (Averre, 2009). Accordingly, the 2004 European Neighbourhood Policy (ENP) and the 2009 Eastern Partnership Programme (EaP) have sought to deepen the EU's ties with these countries through negotiating bilateral agreements which call for economic and political alignment with the EU in return for the benefits of closer association, namely preferential trade access. The resulting AA, negotiations for which were undertaken by the EU and Ukraine between 2009 and 2011, was undoubtedly a concrete attempt at bringing Ukraine closer to Brussels.

This section examines the inherent interest of the EU's Ukraine policy by firstly accounting for the systemic pressures driving the EU's action. Thereafter, through surveying both the policy documents and the opinions of EU practitioners, ${ }^{5}$ it

3 In neoclassical realism, the researcher is charged with getting "inside the heads of key state decision makers" (Rose, 1998). However, given the difficulty for the researcher in gaining access to the relevant decision-makers, whether heads of state, foreign ministers, or in the case of the EU, high-ranking officials in the EEAS and Commission, researchers have to make do with accessing lower-ranking practitioners and utilising archive research skills.

4 Ukraine is the largest country of the shared neighbourhood in most objective terms: population, size and attractiveness of its economy and geographic territory.

5 Semi-structured interviews were conducted with four EU officials (two from EEAS and one from both DG Trade and DG Energy) in Brussels, Kyiv and Moscow in September/October 2013. Interviews were also conducted with two Ukrainian and one Russian official(s). While the data collected via interviews cannot be claimed to be wholly representative, it nevertheless provides important triangulation and offers an interesting 'snapshot' of the examined phenomenon. 
is argued that the interests for the EU to deepen relations with Ukraine through the offer of an AA came down to a mix of material interests (trade), regime promotion interests (growing democracy) and security interests (ensuring a proEU and stable Ukraine).

\subsection{Systemic pressures}

Examining in the systemic incentives for the EU to extend the offer of an AA to Ukraine, one has to start at the broader international level. The argument that the international system is gradually transitioning from unipolarity to multipolarity is nearly universally accepted, although much debate exists on how quickly this transformation is occurring (Brooks \& Wohlforth, 2010; Layne, 2012). Whereas unipolarity resulted in the pacification of "the salience and stakes of balance-of-power politics" amongst large secondary powers (Wohlforth, 1999), multipolarity could precipitate "rising nationalism and mercantilism, geopolitical instability, and great power competition" (Layne, 2012).

In the context of Europe, clearly there is a bipolar power distribution between the EU and Russia. While the EU cannot project or utilise the same level of hard power as Russia (Toje, 2011), it is however undeniably a far stronger economic power; representing the world's largest single market and the second largest provider of foreign direct investment.

Russia's relative economic decline since the fall of the Soviet Union vis-à-vis the EU's greater economic integration in the same period grants the EU clear economic power dominance in Europe. ${ }^{6}$ For instance, the EU's single market produced a GDP PPP of 16,092 billion dollars in 2012, compared to Russia's total of 2,486 billion dollars (GDP PPP statistics sourced from World Bank). Indeed, an element of trade interdependency does exist between the EU and Russia: total trade between the EU and Russia for 2012 was 336,474 million euros (trade statistics sourced from Eurostat). For the EU, this placed Russia as the third most important partner behind only the United States (291,880 million euros) and China (143,874 million euros) while for Russia, this placed the EU first, a long way ahead of China (64,119 million euros) in second.

The economic data illustrates that while interdependency is present between the EU and Russia, trade is nevertheless asymmetrically titled in favour of the EU given that the EU is less dependent on Russia as a trading partner than vice versa (Casier, 2011). Asymmetrical independence between two states, whether in relation to military capabilities or economics and trade, represents a source

6 For an early look at the EU's economic power under a realist scope, see Grieco 1995. 
of power for the less dependent state over the more dependent one. As Keohane and Nye (1973, p. 159) argue:

economic sources of power, which are easier to apply gradually and increasingly than threats of force and which are less offensive to national prestige and dignity, are often the handiest means of dealing with other states 'policies that impose significant costs on one's own state.

Accounting for the European regional economic power distribution in the scope of Ukraine, it is clear that there was an opportunity and an incentive for the EU to utilise its economic asymmetry over Russia to gain a more favourable outcome in Ukraine. Interestingly, of the four EU practitioners interviewed, three mentioned the relative economic strength of the EU compared to Russia as being of importance in the context of Ukraine, with two claiming that Russia was a power in decline which granted the EU an "opportunity". Furthermore, all of the EU officials interviewed agreed that the EU had self-interest in deepening ties with Ukraine through the AA. All spoke of Ukraine's great "potential", whether as a market for the EU or as a fully fledged democracy with a pro-EU leaning. As one official from the EU's DG Trade stated, "the EU's self-interest [in Ukraine] should not be underestimated" and that "because the EU shares a border with Ukraine, it will always remain a focus."

\subsection{Trade interests}

In relation to trade, the key aspect of the AA was the EU's offer of a Deep and Comprehensive Free Trade Agreement (DCFTA) which essentially represented

a framework for modernising its [Ukraine's] trade relations and for economic development by the opening of markets via the progressive removal of customs tariffs and quotas, and by an extensive harmonisation of laws, norms and regulations in various traderelated sectors (European Commission, 2013).

Although Ukraine currently only represents the EU's $22^{\text {nd }}$ largest trading partner (1.1\% of two-way trade), ${ }^{7}$ EU-Ukraine trade has increased more than double in the last decade. Ukraine is already an important source of crude materials and manufactured goods but also a growing source of agricultural products. Add in Ukraine's favourable geographical proximity to the EU and it is clear that Ukraine is a key strategic economic partner for the EU moving forward.

7 For Russia, Ukraine is its fourth largest trading partner (3.7\% of two-way trade). 
All of the interviewed EU officials agreed that trade was a key aspect of the EU's interaction with Ukraine. A European External Action Service (EEAS) official in Moscow stated that Ukraine had "important economic potential" and was an attractive partner for the EU. Furthermore, an EEAS official in Kyiv mentioned that "there is a long tradition [in Ukraine] of having a pretty well educated labour force", so the challenge but incentive for Ukraine is to become "a much more attractive place for international investment" which would "turn Ukraine's potential as a manufacturing location [into] a reality." Consequently, as conveyed by a DG Trade official, there was "self-interest" for the EU to use the "competitiveness" of the "Single European Market" to grow trade with Ukraine. Therefore, growing trade links represented an opportunity for the EU to harness the potential material gains on offer in Ukraine.

\subsection{Regime promotion interests}

It is also argued that the EU had significant interest in regime promotion in Ukraine, undertaken through promoting democracy, human rights and rule of law. There is clearly a strong normative aspect to the AA, based on the underlying strategy of undertaking "political association and economic integration based on the respect for common values" (European Commission, 2009). Under the heading 'Democracy, rule of law, human rights and fundamental freedoms' (Article 2.1), the EU prioritised reform which: strengthens "institutions guaranteeing democracy and the rule of law"; ensures the "independence of the judiciary and the effectiveness of the courts and of the prosecution as well as of law enforcement agencies"; and a demand for "comprehensive cooperation on the protection of human rights and fundamental freedoms" (European Commission, 2009).

The prevailing perception amongst the interviewed officials was that Ukraine's democratic failings presented noticeable hurdles to growing EU-Ukrainian relations. An EEAS official in Moscow noted that because of the difference in regime styles, "mutual trust is lacking" between the EU and Ukraine. Additionally, an EEAS official in Kyiv stated that Ukrainian political leaders whether "Yanukovych or Yushchenko or Yulia [...] are all part of the same system and I think Russia is able to work reasonably effectively with any of them". Consequently, the EU's desire for a democratic and normatively aligned Ukraine was seen as a kind of pre-requisite for deepening economic and political relations between the two. A situation in Ukraine where the status quo prevailed (called "managed democracy" by one official), or perhaps worsening authoritarianism, was perceived as being detrimental to the EU's self-interest, and perhaps beneficial to Russia's. 


\subsection{Security interests}

Arguably, the material interests inherent to trade and the regime promotion interests stemming from democracy promotion, both of which can be discerned in the EU's AA, ultimately point to an overarching security interest in Ukraine. Indeed, Christou (2010) identified both normative and material security logics at the heart of the EU's neighbourhood policies which were built on the objective of securing "security, stability and peace". Normative security narratives inherent to the ENP and EaP stressed the "pursuit of extending the European peace project for the purpose of avoiding the creation of new dividing lines in Europe" (Christou, 2010, p. 415). Material security narratives focussed on tangible threats, such as "organised crime, violent conflict, illegal immigration and terrorism", which had the potential to spill over into the EU (Christou, 2010, p. 417).

All of the interviewed EU officials were cognisant of the security issues endemic to the EU's Eastern Neighbourhood and Ukraine. Most cited the influence of Russia as a competitor to the EU in Ukraine as a potentially destabilising factor in Ukraine. An official from DG trade remarked that "Russia is not interested in cooperation" and has a "far more zero sum approach". Although all the interviewees felt Russia was no longer the great power it was, "weak" and "insecure" were popular labels, all agreed that they could have influence in repositioning Ukraine towards Moscow. Therefore, one can discern that the EU's AA aims rested on an ultimate goal of fostering a secure, and EU-facing, Ukraine. As an EEAS official in Kyiv stated, "[a] more independent and a more sovereign Ukraine in cooperation with the EU [would be] a good outcome."

\section{Analysing the EU's reaction to the 2013-2014 Ukraine crisis}

The Ukraine crisis, which ostensibly began in late October 2013 with Viktor Yanukovych's decision to not sign the EU's AA in favour of moving closer to Moscow, which has more recently escalated and resulted in the Russian annexation of Crimea in March 2014 and the rise of pro-Russian factions in the east of Ukraine thereafter, has undoubtedly been a massive test of the EU's foreign policy capabilities. The current geopolitical quagmire in Eastern Europe, particularly in the corridor of states where the EU and Russia's spheres of influence overlap (Belarus, Moldova and Ukraine), has resulted in growing competition between the EU and Russia for influence in these states, especially Ukraine. Consequently, the deterioration of the situation in Ukraine was partly 
due to the growing contention in the neighbourhood policies of both Russia and the EU, which left Ukraine precariously in the middle and unable to maintain its preference for a multi-vector approach.

The EU's reaction to the crisis thus far has been the source of much criticism from foreign policy analysts and commentators alike. Firstly, in response to Yanukovych's decision to not sign the AA in late October, despite popular support amongst Ukrainian citizens, the EU was criticised for its weak stance which focussed on softly assuaging Yanukovych back towards the EU through focussing on "greater dialogue". Such a strategy proved ineffective in the face of Russia's strong use of zero-sum coercions (the threat of higher gas prices) and incentives (the offer of a 15 billion US dollar loan to stave off imminent default). Secondly, after Russia's annexation of Crimea in March through a forced, and potentially dubious, referendum, the EU was unable to respond in a strong or capable manner. Despite the clear violation of both Ukraine's territorial integrity and of international law, the EU struggled to coherently and strongly respond to Russia. Although the EU was quick to condemn Russia in official statements, in the end it only managed to impose largely superficial sanctions while Russia exercised carte blanche in Crimea. The EU, out of all the Western powers opposed to Russian action (whether the United States, Canada or individual EU Member States), arguably had the most power to inflict damage on Russia, beyond a pure military response. Indeed, the EU's great importance as a trade and energy partner to Russia gave it great capacity to inflict pain on Putin's regime, although at some internal cost.

The unfolding crisis has, again, illustrated the EU's difficulty in being an effective international actor. Despite having clear interests in Ukraine, as discussed in the previous section, the EU was arguably unable to adequately filter these through its foreign policy apparatus which resulted in a litany of ineffective policies and decisions. This paper argues that the EU's foreign policy decisions were constrained in three key ways: a miscalculation by EU decisionmakers in regards to both Ukraine and Russia's likely responses to the AA; a too rigid demand for normative reform in Ukraine; and most glaringly, a crippling reliance on consensus politics which impeded a strong and quick response to the unfolding crisis. 


\subsection{The EU's miscalculation}

While the EU rightfully had a self-perception as the dominant economic actor in the European regional setting, its perceptions of both Ukraine and Russia were arguably flawed, which led to inadequate foreign policy decisions, particularly in the midst of the deteriorating Ukraine crisis.

As discussed earlier, the EU clearly perceived Ukraine as a viable target state where it could push its economic and political self-interest. However, the EU underestimated the likelihood of Yanukovych rejecting the AA. The majority of the interviewed officials spoke of the signing of the AA as nearly a forgone conclusion. An EEAS official in Kyiv stated that "it is pretty likely that the association agreement will be signed and it is fairly likely that it will be subsequently ratified." Furthermore, key EU officials, such as Štefan Füle, made repeated guarantees of a Ukrainian signature of the AA at the Vilnius summit. Subsequently, the EU was arguably shocked and paralysed at Yanukovych's decision to eschew the AA in favour of Russia's counter-offer, despite the fact that Ukrainian leaders, particularly Yanukovych, have long had a reputation for flip-flopping, favouring a multi-vectored approach over siding completely with either the EU or Russia.

In the context of Russia, the EU perceived Russia as being an economically weak state whose bark was much worse than its bite. Although the EU, as evident in the responses of the interviewed officials, was clearly conscious of Russia's desire to curtail the EU's encroachment into their sphere of special privilege, they clearly underestimated the lengths Russia was prepared to go to fulfil this goal. Firstly, the EU misperceived Russia's ability to employ effective zero-sum strategies to cajole Ukraine into rejecting the AA. Secondly, the EU did not believe Russia would be brazen enough to annex Crimea and actively destabilise the east of Ukraine, even though this strategy closely mimicked the strategy employed by Russia in Georgia in 2008. While Russia's economic frailties and declining power may inhibit its long-term success, clearly in the short term it has proved more geopolitically adept than the EU perceived they could be.

Ultimately, the EU's miscalculation of both Ukraine and Russia's response to its AA policy manifested itself in a foreign policy decision which lacked a contingency plan for a worst-case scenario. The EU's inability to adequately calculate the geopolitical nature of the EU-Russia-Ukraine triangle led to it being overshadowed in the contest by the United States, a power whose sphere of influence has retreated significantly from Eastern Europe in the past two decades. As Walt has argued, because of greater national interests, "Russia is 
willing to pay a much higher price to get what it wants in the Ukraine than the U.S. or Europe", something which the EU arguably misinterpreted (Hamilton, 2014).

\subsection{The EU's rigid normative power self-perception}

Unequivocally, in the past two decades, the EU has made conscious efforts to promote the so-called tenets of Europeanness: democracy, human rights, rule of law and market economy principles (Zielonka, 2013). However, the EU's purported normative power was arguably built on an overestimation of the EU's power to affect normative change in third countries thanks to its ostensible success in facilitating democratic change in the ten erstwhile communist countries which acceded into the Union in 2004 and 2007 (Pridham, 2005). Comparatively, the EU's track record in countries which were not offered the carrot of membership has been less than stellar and at times grossly ineffective (Petrovic, 2013).

In the context of Ukraine, although the promotion of the EU's core normative ideals made sound strategic sense, as argued in the previous section, the EU's foreign policy model for achieving desired transition has proved flawed. Despite no longer dangling a carrot of membership, the EU has continued to utilise a strategy of conditionality, whereby incentives are offered for states to implement the prescribed normative reforms. The EU's normative demands in Ukraine are undoubtedly long-term in scope, to be implemented over a decade, but they arguably forget to adequately address the tough short-term reality Ukraine faces in its effort to reform. As an EEAS official in Kyiv stated, "the association agreement hardly requires anything from the EU side but it requires massive changes from the Ukraine side, and they don't get very much in return directly."

The rigidness of the EU's normative demands was strongly felt amongst Ukrainian political elites and duly affected their foreign policy response. Interviews with two Ukrainian officials revealed that while Ukraine had a "popular demand for Europeanization", they felt Ukrainian national interest should take "precedence" with regards to the EU's AA offer. One official claimed that "the EU's weakness for now is this stubbornness in demanding full implementation of European values like democracy". Furthermore, it was argued that the "they [EU] don't understand the importance of geopolitical factors [...] they are trying to push for some technical things and have such short-term value and could be settled in the mid-run or long-run if the association agreement is in effect." Additionally, the other official was cautious about the agreeability of the EU in allowing Ukraine 
to maintain its long-held multi-vector approach of balancing its foreign policy between East and West given its strong policy demands.

Therefore, it is argued that the EU's rigid model for pursuing its normative demands in Ukraine was detrimental to the effectiveness of its overall foreign policy. The inability of the EU to employ a more malleable normative policy made it less of an attractive partner to Ukraine and arguably allowed Russia to exploit the "double-standards" of the EU's normative demands. Consequently, in the aftermath of Yanukovych's decision to not sign the AA, while Russia played a strong zero-sum game focussed on geopolitics, the EU maintained its rigid and dated normative foreign policy model. Certainly, more recently, the EU has appeared more open to relaxing its tough stance regarding its normative demands, by rushing through the signature of the AA, but one wonders whether they have missed the boat.

\subsection{The EU's Achilles' heel: consensus politics}

Unsurprisingly, in the context of Eastern Europe, differing Member States preferences have had an important influence on the EU's foreign policy decisions. Historically, EU Member States have had diverging interests in the East, ranging from the pro-Russian "Trojan Horses" Cyprus and Greece to the anti-Russian "New Cold Warriors" Poland and Lithuania, with the remaining Member States occupying positions in the middle (Leonard \& Popescu, 2007). The EaP process, from which the AA emerged, was driven largely by Polish-Swedish collaboration, who were later joined by Lithuania as well as more tepid support from the remaining three in the Visegrád Group: Czech Republic, Hungary and Slovakia (Copsey \& Pomorska, 2013). However, the internal divisions among EU Member States were a major reason a 'membership perspective' was never added to the EaP instrument, which subsequently has been cited as a major flaw of the EU's policy.

With regards to the EU's AA offer to Ukraine, the majority of the interviewed officials conceded that diverging interests among EU Member States hurt the effectiveness of its foreign policy. An EEAS official in Moscow made an observation that the EU is at its strongest externally when it is internally cohesive, but with regards to the AA process, the difficult challenge was to make the policy more meaningful and effective. A DG Trade official argued that the EU had a "take it or leave it stance" in Ukraine largely because the EU's "internal divisions hurt its effectiveness." Ultimately, the ambivalence of the Big Three EU Member States (France, Germany, UK) during the AA process hamstrung the EU's power to develop stronger, more geopoliticallyadept policies towards Ukraine. 
More recently, in the immediate aftermath of the Crimean Status Referendum, EU personnel spoke of a strong and swift response which would punish Russia for its action. High Representative Ashton stated that the EU need to send the "strongest possible signals" while Commission President Barroso and Council President Van Rompuy jointly stated "the European Union has a special responsibility for peace, stability and prosperity on the European continent and will continue pursuing these objectives using all available channels" (European Council, 2014). However, in the various Foreign Affairs Council meetings which followed, the EU was unable to consensus-build a strong response, which resulted in only superficial sanctions being adopted to date. Germany's ongoing reluctance, although this has abated significantly, to impose tough sanctions, coupled with a pro-Russian bloc consisting of Cyprus, Bulgaria and Greece, casts serious doubt over the ongoing ability of the EU to compete with Russia in its shared neighbourhood.

Despite Poland's and Lithuania's cheerleading for a strong EU response to the Ukraine crisis, the EU's inability to coherently and quickly formulate an assertive and firm retort clearly shows that the EU is still suffering from what Toje (2008) called a consensus-expectations gap. Despite the intentions of the Treaty of Lisbon to rectify the failings of the EU's actorness and decision-making capacity, the EU still struggles to reach common positions on tough international crises, even when it is occurring in its direct periphery. Consequently, the EU's reliance on consensus politics is the biggest hurdle it has to overcome in its quest to develop strong and self-interested policies; a hindrance that will continue to blight EU foreign policy making until further evolution occurs.

\section{Conclusion}

This paper illustrates the difficulties the EU has in translating its interests into effective foreign policy action. Examining the EU's foreign policy decisions towards Ukraine, through analysing various official documents and interviewing practitioners, it was determined that the EU had a mixture of interests, ranging from trade and regime promotion to security interests. However, in the context of the rapidly escalating crisis in Ukraine, it was argued that the EU failed to act on its interests in an effective manner. Three key issues were identified as detrimental to the EU's foreign policy responses. Firstly, the EU miscalculated both Ukraine's and Russia's response to its foreign policy initiatives. Secondly, the EU's normative power role identity resulted in a rigid normative policy. 
Lastly, due to a lack of coherence, the EU failed to formulate both a strongenough initial policy (the AA) as well as swiftly and adequately respond to the unfolding Ukraine crisis. Therefore, while this paper asserts that the EU does have concrete interests in extending its policy towards Ukraine, the Ukraine crisis illustrates that when a situation becomes threatening and internally polarising, the EU defaults into being a weak and ineffective actor, which without further evolution, will continue to hamstring its international action.

Nicholas Ross Smith is a PhD candidate in politics and International Relations at the University of Auckland. His research interests predominately focus on EU foreign policy in their Eastern Neighbourhood and Russian foreign policy in the post-Soviet setting. Recent peer-reviewed articles have focussed on the external perceptions of the EU's post-Lisbon action and the objective case for the EU enlarging further into the Western Balkans. A list of publications and current projects is available at http://auckland.academia.edu/ NicholasRossSmith

\section{References}

Averre, D. (2009), "Competing Rationalities: Russia, the EU and the "Shared Neighbourhood'," Europe-Asia Studies, vol. 61, no. 10, pp. 1689-1713. http://dx.doi.org/10.1080/09668130903278918

Bressand, A. (2011), 'Between Kant and Machiavelli: EU foreign policy priorities in the 2010s,' International Affairs, vol. 87, no. 1, pp. 59-85. http://dx.doi.org/10.1111/j.1468-2346.2011.00960.x

Brooks, S. G. \& Wohlforth, W. C. (2010), World Out of Balance: International Relations and the Challenge of American Primacy, Princeton: Princeton University Press.

Casier, T. (2011), "Russia's Energy Leverage over the EU: Myth or Reality?" Perspectives on European Politics and Society, vol. 12, no. 4, pp. 493-508. http://dx.doi.org/10.1080/15705854.2011.622963

Christou, G. (2010), 'European Union security logics to the east: the European Neighbourhood Policy and the Eastern Partnership,' European Security, vol. 19, no. 3, pp. 413-430. http://dx.doi.org/10.1080/09662839.2010.526110

Copsey, N. \& Pomorska, K. (2013), 'The Influence of Newer Member States in the European Union: The Case of Poland and the Eastern Partnership,' Europe-Asia Studies, vol. 66, no. 3, pp. 421-443.

European Commission (2009), EU-Ukraine Association Agenda, Brussels: Commission of the European Communities. 
- (2013), EU-Ukraine Deep and Comprehensive Free Trade Area, Brussels: Commission of the European Communities.

European Council (2014), Joint statement on Crimea by President of the European Council Herman Van Rompuy and President of the European Commission José Manuel Barroso, Brussels: Council of the European Union.

Forsberg, T. (2013), “The power of the European Union: What explains the EU's (lack of) influence on Russia?” Politique européenne, vol. 39, no. 1, pp. 22-42.

Hamilton, P. (2014), 'Professor Stephen Walt on the Crisis in Ukraine,' Boston Global Forum. Retrieved from http://bostonglobalforum.org/2014/03/professor-stephenwalt-on-the-crisis-in-ukraine/ [accessed Apr 2014]

Hyde-Price, A. (2007), European Security in the Twenty-First Century: The Challenge of Multipolarity, New York: Routledge.

Keohane, R. \& Nye, J. (1973), 'Power and interdependence,' Survival: Global Politics and Strategy, vol. 15, no. 4, pp. 158-165.

Layne, C. (2012), "This Time It's Real: The End of Unipolarity and the Pax Americana," International Studies Quarterly, vol. 56, no. 1, pp. 203-213.

http://dx.doi.org/10.1111/j.1468-2478.2011.00704.x

Leonard, M. \& Popescu, N. (2007), A Power Audit of EU-Russia Relations, London: European Council on Foreign Relations.

Petrovic, M. (2013), The Democratic Transition of Post-Communist Europe: In the Shadow of Communist Differences and Uneven EUropeanisation, Basingstoke: Palgrave Macmillan. http://dx.doi.org/10.1057/9781137315359

Pridham, G. (2005), Designing Democracy: EU Enlargement and Regime Change in Post-Communist Europe, Basingstoke: Palgrave Macmillan. http://dx.doi.org/10.1057/9780230504905

Rose, G. (1998), 'Neoclassical Realism and Theories of Foreign Policy,' World Politics, vol. 51, no. 1, pp. 144-172. http://dx.doi.org/10.1017/S0043887100007814

Schweller, R. L. (2004), 'Unanswered Threats: A Neoclassical Realist Theory of Underbalancing,' International Security, vol. 29, no. 2, pp. 159-201. http://dx.doi.org/10.1162/0162288042879913

Sjöstedt, G. (1977), The External Role of the European Community, Farnborough: Saxon House.

Thomas, D. (2012), 'Still Punching below Its Weight? Coherence and Effectiveness in European Union Foreign Policy,' JCMS: Journal of Common Market Studies, vol. 50 , no. 3 , pp. $457-474$.

Toje, A. (2008), “The Consensus_Expectations Gap: Explaining Europe's Ineffective Foreign Policy," Security Dialogue, vol. 39, no. 1, pp. 121-141. http://dx.doi.org/10.1177/0967010607086826 (2011), 'The European Union as a Small Power,' JCMS: Journal of Common Market Studies, vol. 49, no. 1, pp. 43-60. http://dx.doi.org/10.1111/j.1468-5965.2010.02128.x 
Toje, A. \& Kunz, B. (2012), 'Introduction: neoclassical realism in Europe,' in A. Toje and B. Kunz (eds.) Neoclassical Realism in European Politics: Bringing Power Back In, Manchester: Manchester University Press.

Whitman,R.G.(2011), Normative Power Europe: Empirical and TheoreticalPerspectives, Basingstoke: Palgrave Macmillan. http://dx.doi.org/10.1057/9780230305601

Wohlforth, W. C. (1999), 'The Stability of a Unipolar World,' International Security, vol. 24, no. 1, pp. 5-41. http://dx.doi.org/10.1162/016228899560031

Zielonka, J. (2013), “Europe's new civilizing missions: the EU's normative power discourse," Journal of Political Ideologies, vol. 18, no. 1, pp. 35-55.

http://dx.doi.org/10.1080/13569317.2013.750172 